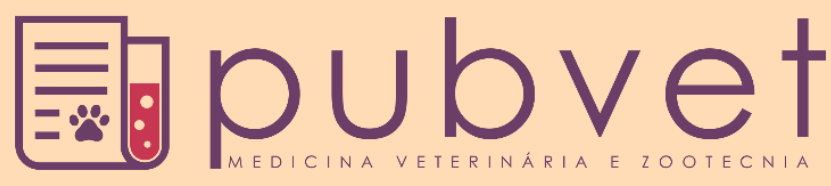

ISSN $1982-1263$

https://doi.org/10.31533/pubvet.v12n12a227.1-9

\title{
Desmistificando a carne suína
}

\author{
Cláudia Moreira dos Anjos ${ }^{1}$, Franz Dias Gois ${ }^{1}{ }^{\ominus}$, Cinthia Maria Carlos Pereira*2 ${ }^{\bullet}$ \\ ${ }^{1}$ Discentes do Programa de Pós-Graduação em Ciência Animal, Universidade Estadual de Santa Cruz. (UESC), Ilhéus - Bahia, Brasil; \\ ${ }^{2}$ Professora do Departamento de Ciências Agrárias e Ambientais, Universidade Estadual de Santa Cruz. (UESC), Ilhéus - Bahia, Brasil. \\ *Autor para correspondência: cmcpereira@uesc.br
}

\begin{abstract}
RESUMO. A carne suína sempre foi circundada de opiniões, tanto dos apreciadores, quanto das pessoas que não a consomem. A divergência entre os dois lados sempre existiu e de tempos em tempos, conforme a evolução das ideias sobre a produção animal, os parâmetros vão se modificando. A Bíblia afirma a proibição do consumo da carne suína é por considerar o suíno um animal impuro. Milhares de anos depois, na era feudal, comer carne suína era sinônimo de riqueza. No entanto, atualmente mitos são criados sobre a carne suína baseados em situações antigas que não se aplicam ao sistema de criação atual. Antes era um suíno do tipo banha e atualmente é do tipo carne, além disso, grande parte da população ainda apresenta o pensamento estereotipado sobre "comer carne suína faz mal e é perigosa à saúde" e "a carne suína tem muita gordura e colesterol". De modo que, esses mitos estão sendo desmistificados aos poucos, devido ao aumento da exigência do mercado consumidor, havendo um aumento de tecnologias dentro das granjas produtoras de suínos com o melhoramento genético em conjunto com estratégias de manejo sanitário, ambiental e nutricional adequados. A qualidade da carne oferecida hoje é superior a que era oferecida há 30 anos, sendo um resultado positivo, que pode auxiliar na promoção da carne suína diante baixo consumo pelos brasileiros. Sendo assim, é necessário demonstrar a mudanças das criações, melhorar o marketing para que o pensamento seja modificado e a carne suína seja aceita.
\end{abstract}

Palavras chave: consumo, doenças, produção animal, sistema de criação, suíno

\section{Demystifying pork}

ABSTRACT. The pork has always been opinion by surrounded of both the sympathizer, as people who do not consume. The divergence between the two sides has always existed and from time to time as the evolution of ideas on animal production, the parameters are modified. The Bible affirmed the prohibition of consumption by considering the pig an unclean animal. Thousands of years later in the feudal era, eating pork was synonymous with wealth. Currently, due to old situations that were real, myths have been created over the meat. Previous was a type lard pig and is currently the type meat, much of the population still presents the stereotypical thinking about "eating pork is bad and dangerous to health" and "swine meat has too much fat and cholesterol". So, these myths demystified being gradually increased due to the requirement of the consumer market, there is an increase in the producing technology pig with genetic melioration in conjunction with hygienical management strategies, environmental and nutritional appropriate. The quality of meat offered today is greater than it was offered to 30 years ago, with a positive result, which can assist in promoting pork on low consumption by Brazilians. Therefore, it is necessary to demonstrate the changing creations, improve marketing for thought to be modified and the pork is accepted.

Keywords: animal production, consumption, creation system, diseases, swine 


\section{Desmistificando la carne de cerdo}

RESUMEN. La carne de cerdo siempre ha sido rodeada de opiniones, tanto de los apreciadores, como de las personas que no la consumen. La divergencia entre los dos lados siempre existió y de vez en cuando, según la evolución de las ideas sobre la producción animal, los parámetros se van modificando. La Biblia afirma la prohibición del consumo de la carne porcina por considerarla proveniente de un animal impuro. Miles de años después, en la era feudal, comer carne porcina era sinónimo de riqueza. Sin embargo, actualmente los mitos son creados sobre la carne de cerdo basados en situaciones antiguas que no se aplican al sistema de producción actual. La mayoría de la población todavía presenta el pensamiento estereotipado sobre "comer carne porcina hace mal y es peligrosa para la salud" y "la carne de cerdo tiene mucha grasa y colesterol" . De modo que estos mitos están siendo desmitificados poco a poco, debido al aumento de la exigencia del mercado consumidor, habiendo un aumento de tecnologías dentro de las granjas productoras de cerdos con el mejoramiento genético en conjunto con estrategias de manejo sanitario, ambiental y nutricional adecuadas. La calidad de la carne ofrecida hoy es superior a la que se ofrecía hace 30 años, siendo un resultado positivo, que puede auxiliar en la promoción de la carne de cerdo ante bajo consumo por los brasileños. Siendo así, es necesario demostrar los cambios de las creaciones, mejorar el marketing para que el pensamiento sea modificado y la carne porcina sea aceptada.

Palabras clave: consumo, enfermedades, producción de animales, sistema de cría, porcino

\section{Introdução}

O suíno foi originado a partir do javali, possivelmente na Europa, a cerca de milhares de anos atrás. Foi domesticado com a finalidade de alimentação pelos povos que deixaram de ser nômades. O impasse sobre o consumo da carne é um assunto antigo e sempre foi cercado de prós e contras, devido às crenças e a maneira de como os animais era criada (Sarcinelli et al., 2007).

Hoje em dia, a questão do consumo da carne suína vem sendo explorada por ser uma carne que tem uma grande aceitabilidade pelo público, por conta do sabor extremamente agradável. No entanto, uma grande parte da população não a consome por receio de se contaminar com alguma doença ou acreditando que a carne possui altos índices de gordura (Roppa, 2006).

A maneira como o os suínos são produzidos atualmente, de acordo com normas técnicas dentro dos padrões sanitários e nutricionais, isenta os animais de se contaminarem e transmitir essas doenças aos serem humanos (Roppa, 2006; Viana, 2012). A biosseguridade tem sido o carro chefe na produção dos animais, com intuito de manter as melhores condições das criações de suínos, objetivando uma diminuição nas disseminações de doenças, na mortalidade animal e nos prejuízos a granja. Dessa forma, resultando em um aumento na produção (ganho de peso), qualidade final do suíno abatido (livre de qualquer doença que possa ser transmitida ao ser humano) e consequentemente, trazendo maior lucro ao produtor (ABCS, 2011). Além disso, o suíno é hoje considerado importantíssimo para a medicina humana, pois a partir desses animais, muitas medicações são obtidas, cirurgias experimentais e xenotransplantes podem ser realizadas (Roppa, 2006; Vaena et al., 2013).

Dessa forma, objetiva-se demonstrar que os mitos criados em torno da carne suína, não são mais fundamentados, devido às melhorias no processo de criação desses animais.

\section{Origem e história}

Os primeiros suínos (Sus domesticus) apareceram na terra há mais de 40 milhões de anos atrás. Acredita-se que a esses sejam descendentes dos Sus scrofa, uma espécie de javali que habitava grandes regiões da Europa. Sendo que a sua domesticação é datada por volta de aproximadamente 10.000 anos atrás, onde foi realizada possivelmente por antigos nômades que ao fixarem aldeias, cultivavam cereais e trigo para alimentação da comunidade e tinham como principal fonte de alimento os suínos, após a sua domesticação (Sarcinelli et al., 2007).

Ainda na antiguidade, já ocorriam preconceitos e restrições quanto ao consumo da carne suína, mas havia também os que consumiam em grande quantidade. Algumas passagens da Bíblia Sagrada como, por exemplo, no livro de Deuteronômio capítulo 14 e no livro Levítico capítulo 11 
encontramos com seguinte título "Os animais puros e os impuros", podendo ser lido no versículo;

"É proibido comer carne de porco. Para vocês o porco é impuro, pois tem o casco dividido, mas não rumina. Não comam nenhum desses animais, nem mesmo toquem neles quando estiverem mortos. Todos eles são impuros."

Além dos livros citados, Moisés, o legislador do povo Hebreu, vetou o consumo da carne de porco ao seu povo, para que pudesse ser evitada uma disseminação de doenças parasitárias que eram comuns à época, como a solitária (teníase). Por outro lado, na Grécia Antiga havia criações de porcos para que pudesse ser sacrificado como uma oferta aos deuses. No Império Romano era uma carne muito consumida nas festas, tanto pelos nobres quanto pelo povo. No período da Idade Média era alto o consumo da carne de porco. Tinha como significado principal para as pessoas que consumiam em grande quantidade a luxúria e a gula. Era sinônimo de força e poder dos nobres feudais em oposto aos camponeses que realizavam refeições fartas em vegetais (Roppa, 2006; Fávero \& Figueiredo, 2009).

Os suínos, ainda denominados de porcos, foram trazidos até a América por Cristóvão Colombo em 1494, povoando grande parte da América do Norte e ao longo dos anos, povoando também alguns países da América do Sul. No Brasil, a introdução dos suínos foi realizada por Martim Afonso de Souza em 1532. Os animais brasileiros eram cruzamentos entre raças portuguesas, como: Alentejana, Transtagana, Galega, Bizarra, Beiroa e Macau. As novas raças consideradas brasileiras foram surgindo de acordo com os novos indivíduos que foram gerados desses cruzamentos (Fávero \& Figueiredo, 2009).

Durante todo esse período, não existia uma preocupação por parte da população, em específico dos criadores de suínos para que houvesse uma melhora na qualidade do rebanho nacional. No entanto, em 1955, foi fundada a Associação Brasileira de Criadores de Suínos (ABCS), com $\mathrm{o}$ intuito favorecer $\mathrm{o}$ desenvolvimento tecnológico da criação de suínos no país, principalmente voltado para o melhoramento genético do rebanho suíno brasileiro (Fávero \& Figueiredo, 2009).

\section{Evolução da carne suína}

A criação de suínos no Brasil pode ser dividida em duas fases. A primeira até o final dos anos 70 e a segunda do final dos anos 70 até os dias atuais. Essa divisão se deu pela mudança na maneira com que os produtores brasileiros mantinham suas produções. Antes, não se falava sobre melhoramento genético, controle sanitário e zootécnico, e qualidade final da carcaça. No entanto, com o passar dos anos, o mercado consumidor ficou mais exigente resultando no aumento da pressão por modificações no sistema de criação de suínos (Carvaho, 2007; Poletto et al., 2001). Até o final da década de 70 , buscava-se uma carcaça com dupla aptidão, contendo carne (proteína) e banha (energia). O porco possuía uma conformação corporal de 50\% de dianteiro e 50\% de traseiro, sendo ideal para os produtores da época, tipificado como porco tipo banha, onde os animais possuíam altos teores de gordura na carcaça e era abatido aos seis meses de idade. Entretanto, com o aumento da expansão da produção agrícola no Brasil, o óleo de soja se tornou comum na casa dos brasileiros devido à facilidade e o baixo custo, associado ao fácil acesso e armazenamento, ao contrário da banha que necessitava de maior espaço para armazenamento e para que pudesse ser utilizada carecia de uma maior mão de obra. Contudo, nesse período, o pensamento sobre as condições higiênico-sanitárias das criações, na saúde dos animais e nas consequências de como a falta de higiene poderiam ser refletidas na carne, começou a ser modificado.

A maior parte das criações nessa época era no meio rural. Os animais eram alocados em pocilgas com lama, sem controle sanitário. Dessa maneira, o mercado da carne suína brasileira era apenas para consumo interno. Cerca de $50 \%$ ou mais da carne consumida no país era no meio rural, a outra parte se dava no meio urbano, onde as carnes eram distribuídas aos açougues. As criações de suínos, até então eram consideradas artesanais e é desse período que advém a maioria dos mitos sobre a carne suína (Poletto et al., 2001; Roppa, 2006; Carvaho, 2007).

A partir do final dos anos 70, a ideia de aperfeiçoar o rebanho suíno e oferecer uma melhora na qualidade da carne suína foi crescente, ocorrendo tanto a nível nacional como internacional. Houve uma maior atenção e exigência por parte da população consumidora em relação ao setor, havendo uma pressão sobre o mercado para avanços na produtividade animal, visto que ocorreu uma redução na demanda de banha, pois a população começou a se preocupar com a questão da saúde, perdendo assim espaço 
para os óleos vegetais. Com essas novas exigências, o produtor pôde ver o suíno como um produtor de carne por excelência, contribuindo assim pra que os produtores aprimorassem suas criações, buscando-se então uma carne com menos gordura e maior quantidade de carne. Dessa maneira, foram construídas estações para avaliação de suínos, com o objetivo de realizar o teste de progênie, que visa testar o desempenho de reprodutores selecionados com base na avaliação da carcaça dos seus filhos. Assim, com a utilização de técnicas de melhoramento genético, melhoria na nutrição dos animais e novas tecnologias no sistema de criação foram-se aprimorando as matrizes e consequentemente sua prole (Costa et al., 1984; cannon et al., 1996; Fávero \& Guidoni, 2001; Roppa, 2006). De acordo com os resultados das melhorias genéticas, mudança do pensamento sobre a alimentação da população e exigência do mercado, a conformação corporal do suíno foi sendo modificada, passando de um animal "tipo banha" para um animal tipificado como "tipo carne", onde sua nova condição passou a ser $30 \%$ (dianteiro) e $70 \%$ (traseiro). Com essa nova conformação, a carcaça dos suínos começou a apresentar um teor menor de gordura, ou seja, uma menor espessura de toucinho na sua carcaça e houve o desenvolvendo uma musculatura mais acentuada, especialmente na região do traseiro, onde se encontram as carnes nobres, como o lombo e o pernil (Roppa, 2006).

Em 1958, a ABCS e o Ministério da Agricultura, Pecuária e Abastecimento (MAPA), assinaram um convênio pelo qual o órgão passou a ser responsável pelos registros genealógicos dos suínos. Um trabalho indispensável para o melhoramento do plantel que estava apenas começando no país. A ABCS passou a fazer provas zootécnicas e estimular a realização de exposições desses animais melhorados. Além disso, granjas do Rio Grande do Sul passaram a distribuir reprodutores por todo o país difundindo essas melhorias. Outro fator que contribuiu para redução da idade do abate e melhorias no desempenho dos animais foi a introdução da ração balanceada. Nos anos 70, raças melhoradas advindas de empresas norte-americanas e europeias chegaram ao país, junto com elas vieram melhorias nas técnicas de manejo, nas instalações e nos cuidados sanitários (

Com a inserção do controle zootécnico, foi possível ter um maior controle total da produção, pois, a partir daí foi possível anotações de controle do rebanho, com fichas individuais por animal. Nessas fichas são registradas as datas, a condição e importantes ocorrências como nascimento; coberturas das matrizes; partos; utilização semanal dos machos, enfermidades, mortes, descarte etc. Além dos registros de desempenho produtivo, como pesagens, entre outras importantes mensurações, tais como as medidas morfométricas como a altura, comprimento, circunferência escrotal dos machos reprodutores e condição corporal e medidas de tipo e conformação ( $\underline{\text { ABCS, 2018) }}$.

Segundo Rehfeldt et.al. (2000), a herdabilidade no número de fibras musculares é demonstrado pela influência genética; entretanto, a qualidade ambiental onde o animal é criado, oferecendo suporte nutricional e térmico principalmente, possui uma expressiva e definitiva parcela no desenvolvimento da massa muscular dos animais.

\section{O Consumo da carne suína}

Segundo a Associação Brasileira de Proteína Animal (ABPA), o setor industrial da carne suína tem importante papel no sustento do desenvolvimento econômico de várias regiões do Brasil, gerando empregos no campo, indústria e no comércio dos produtos. Em 2016, a produção brasileira de carne suína foi de 3,73 milhões de toneladas, sendo essa produção mais concentrada nas regiões Sul, Sudeste e Centro-oeste, sendo Santa Catarina o estado brasileiro com maior produção $(26,4 \%)$. Esses números deixam o país firme na quarta posição no ranking de países produtores e exportadores da carne suína (cerca de 732 mil toneladas exportadas em 2016). A carne suína é a carne mais produzida e consumida no mundo, sendo a China o maior produtor, seguida por União Europeia Estados Unidos e Brasil (ABPA, 2016).

Atualmente a ABCS tem promovido campanhas para divulgar a carne suína, mostrando a qualidade e a diversidade dos produtos disponíveis no Brasil. Devido a isso, em 2015, o país conseguiu uma marca histórica no consumo de carne suína, atingindo cerca de $15,1 \mathrm{~kg}$ per capita. No entanto, o consumo ainda é baixo quando comparado as outras fontes de proteína animal, como a de frango (45 kg/hab/ano) e a bovina (40 kg/hab/ano). Mesmo inferior em relação aos outros países consumidores de carnes, o mercado doméstico brasileiro consome quase três milhões de toneladas da carne suína por ano (ABPA, 2016). 


\section{Mitos e verdades sobre a carne suína}

A ABCS, em um trabalho iniciado em 1994 e finalizado em 2004, constatou alguns fatores que contribuíram para que o consumidor não adquirisse a carne suína tanto quanto a carne bovina, mesmo com todos os avanços de melhoramento genético e sanitário. Os fatores constatados foram: cortes pouco práticos na perspectiva do cliente; apresentação inadequada nos pontos de venda, quase sempre associada à gordura; percepção de preço elevado e o preconceito com relação ao impacto sobre a saúde do consumidor. Esses fatores levam a crer que a falta de informação sobre a carne suína, à forma como a qual os animais são criados e as condições sanitárias e nutricionais, influenciam consideravelmente no baixo consumo e até mesmo a rejeição da carne pelos consumidores, devido ao medo de contrair parasitoses ao ingerir a carne (Rodrigues et al., 2012; ABCS, 2018).

$\mathrm{Na}$ tentativa de minimizar o baixo consumo da carne, associada à visão de que não existem cortes práticos da carne, a ABCS lançou o "Manual Brasileiro de Cortes Suínos", que visa demonstrar, por profissionais ligados ao setor de alimentação, desde o açougueiro até o médico, uma referência prática, objetiva e funcional sobre o potencial da carne suína no dia a dia da população. O manual faz uma ponte entre o corte escolhido e o seu uso, proporcionando aos profissionais uma referência a partir do qual podem criar e ampliar infinitamente o potencial de uso do produto (

\section{Transmissão de doenças}

A carne suína é bem aceita pelos consumidores brasileiros, em relação ao sabor. Segundo Roppa (2006), uma pesquisa demonstrou que aceitabilidade é de 92\%. Entretanto, 35\% afirmaram que não consomem a carne por acreditar que "faz mal e é perigosa para a saúde" e $55 \%$ não consomem, pois acreditam que a carne possui "muita gordura e colesterol". Dados que confirmam a falta de informação por parte da população. Então, quando o consumidor afirma que a carne suína faz mal à sua saúde, provavelmente estão se referindo algumas parasitoses que acreditam ser transmitida pela carne suína como a teníase e a cisticercose (Roppa, 2006).

A teníase e a cisticercose são doenças diferentes, apesar de serem causadas pela mesma espécie de cestódeo (parasita). A teníase é caracterizada pela presença do parasita adulto no intestino delgado do ser humano. O ser humano é acometido por duas espécies do parasita, a Taenia solium e Taenia saginata, conhecida como "solitária", que necessitam do suíno e do bovino, respectivamente, para que possam completar o seu ciclo. A transmissão da teníase humana ocorre quando há ingestão de carne suína ou bovina crua ou mal passada contaminada pelo cisticerco (larva), que ao sofrer ação do suco gástrico, perde sua vesícula membranosa e fixam-se a mucosa intestinal pela escólex, permanecendo até desenvolvimento total, cerca de três meses, tornando-se a tênia adulta, causando a teníase. No entanto, se a teníase não for tratada, o parasita em fase adulta libera as proglotes grávidas, repletas de ovos, que são liberadas nas fezes humanas, podendo assim, contaminar o ambiente e pastagens quando não possui saneamento básico, colocando em risco os animais que possivelmente podem se alimentar dessa pastagem contaminada e pessoas que podem ingerir verduras e legumes contaminados (Fortes, 2004; Roppa, 2006; Medeiros et al., 2008).

A cisticercose foi descrita pela primeira vez no século XVI. No entanto, só foi realmente estudada a partir da metade do século XIX, quando pesquisadores comprovaram que a larvas de tênias eram responsáveis pela cisticercose em animais e humanos. Sendo assim, a cisticercose é uma parasitose causada por um hospedeiro intermediário (Medeiros et al., 2008; Roppa, 2006). Para que o suíno seja contaminado com a cisticercose, ele deve ingerir alimentos contaminados com fezes humanas que contenham ovos maduros, sendo esta a principal fonte de contaminação. Depois de ingeridos, os ovos sofrem a ação dos sucos gástricos e pancreáticos dissolvendo a sua camada superficial, liberando os embriões. Estes se fixam nas vilosidades intestinais, perfuram a parede intestinal e caem nos vasos sanguíneos, sendo distribuídos pelo corpo todo, alojando-se principalmente na musculatura, podendo também alojar-se no cérebro, coração e olhos (Moreira et al., 2003; Fortes, 2004; Roppa, 2006). Todo o ciclo do complexo teníase-cisticercose é demonstrado na figura 1.

Dessa maneira, é possível afirmar que práticas de saneamento básico pela deposição correta dos dejetos e a introdução no cotidiano da população sobre a higiene básica, como rigoroso hábito de higiene de lavagem das mãos antes de se alimentar e após evacuações, principalmente, reduzem consideravelmente as reinfecções e 
contaminações, sendo um meio educativo da população, prático e efetivo de profilaxia (Navarro, 2018).

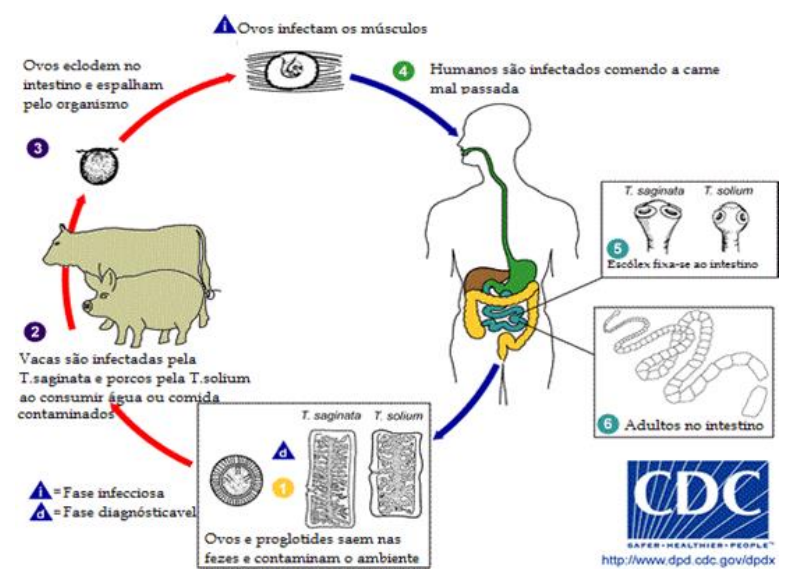

Figura 1. Ciclo do complexo teníase-cisticercose. Fonte: Adaptado CDC (2013)

Um estudo retrospectivo entre 2000 e 2010 , realizado por Viana et al. (2012), relativo ao abate de suínos no abatedouro municipal da cidade de Imperatriz no Maranhão, sob Serviço de Inspeção Municipal (SIM), demonstrou uma redução considerável nos índices de condenação de carcaça acometidas pela cisticercose (Tabela 1). Roppa (2006), também demonstrou a incidência de cisticercose em suínos abatidos sob o Serviço de Inspeção Federal (SIF), no Rio Grande do Sul no ano de 2000 (Tabela 2). Nota-se uma maior incidência de cisticercose em bovinos e ovinos, comparado com os suínos.

Esse resultado possivelmente foi conseguido pela aplicações de boas práticas de manejo, saneamento básico e tecnologia nas granjas. De acordo esses dois estudos é possível afirmar que atualmente, o mito que população acredita sobre os malefícios que a carne suína trás a saúde dos seres humanos por transmitirem parasitoses é desmistificado. Dessa forma, a compra de uma carne com procedência conhecida, com o selo Serviço de Inspeção Federal (SIF) do Ministério da Agricultura, que atesta a qualidade, bem como Estadual (SIE) ou Municipal (SIM). O Sistema de inspeção tem o controle da origem dos produtos. Cada animal abatido é fiscalizado por uma equipe do MAPA, composta por veterinários e auxiliares, além de profissionais contratados pela própria empresa. Em caso de detecção de irregularidades no procedimento de colocação do SI, o processo de produção é interrompido, há a autuação do estabelecimento e a avaliação do risco para a produção. Esse total controle reflete em uma maior segurança, pois o produto se torna livre de doenças que podem causar danos a saúde dos consumidores, como a tuberculose, brucelose e cisticercose, além das infecções e intoxicações alimentares, causadas por microrganismos que contaminam os produtos de origem animal (Roppa, 2006; Viana, 2012; MAPA, 2013).

Tabela 1. Incidência de cisticercose suína em animais abatidos em Imperatriz/MA, sob o controle do SIM, no período de 2000 a 2010

\begin{tabular}{cccc}
\hline Ano & $\begin{array}{c}\text { Animais } \\
\text { Abatidos } \\
\mathrm{N}^{\circ} \text { de casos }\end{array}$ & Cisticercose \% & $\begin{array}{c}\text { Animais } \\
\text { Abatidos } \\
\mathrm{N}^{\circ} \text { de casos }\end{array}$ \\
\hline 2000 & 7.273 & 26 & 7.273 \\
2001 & 7.285 & 18 & 7.285 \\
2002 & 8.497 & 6 & 8.497 \\
2003 & 9.806 & 9 & 9.806 \\
2004 & 11.082 & 9 & 11.082 \\
2005 & 11.157 & 8 & 11.157 \\
2006 & 10.849 & 11 & 10.849 \\
2007 & 9.107 & 1 & 9.107 \\
2008 & 10.533 & 3 & 10.533 \\
2009 & 11.520 & 0 & 11.520 \\
2010 & 11.026 & 0 & 11.026 \\
Total & 108.135 & 91 & 108.135 \\
\hline
\end{tabular}

Fonte: Viana et al. (2012.

Tabela 2. Incidência de Cisticercose em animais abatidos com SIF, no Rio Grande do Sul

\begin{tabular}{lccc}
\hline & $\begin{array}{c}\text { Animais } \\
\text { Abatidos }\end{array}$ & $\begin{array}{c}\text { Animais com } \\
\text { Cisticercose }\end{array}$ & $\begin{array}{c}\text { \% com } \\
\text { Cisticercose }\end{array}$ \\
\hline Bovinos & 812.001 & 29.958 & 3,69 \\
Ovinos & 197.759 & 1.016 & 0,51 \\
Suínos & 3.636 .842 & 11 & 0,003 \\
\hline
\end{tabular}

Fonte: Roppa (2006).

Inversamente ao que a população acredita sobre a carne suína fazer mal a saúde, os animais criados de forma adequada, ou seja, dentro dos padrões sanitários e nutricionais, alimentados com ração de qualidade e comprando uma carne de boa procedência, não há risco algum para a população de contrair alguma parasitose. Animais criados em sistemas intensivos, sem acesso a fezes de humanos, reduz-se praticamente a zero os casos de verminoses, pois nesses tipos de criações a limpeza e desinfecção evitam que o endoparasita complete seu ciclo de vida impedindo a sua disseminação ( $\underline{\mathrm{ABCS}, 2011})$

\section{Carne gordurosa}

Como já citado anteriormente, a conformação corporal e aptidão do suíno mudou devido às exigências do mercado. No entanto, grande parte da população ainda deixa de consumir a carne 
suína acreditando que a mesma ainda é rica em gorduras e colesterol e pode fazer mal a saúde. Hoje, a carne suína, resultou de uma evolução tecnológica da indústria alimentícia, oferecendo uma carne com reduzido teor de gorduras, calorias e colesterol em relação há 25 anos atrás (Roppa, 2006; Magnoni \& Pimentel, 2007). Assim, devem ser desmitificados esses índices sobre a carne. Um corte magro de 100 gramas atualmente possui cerca $60 \mathrm{mg}$ de colesterol, sendo que a American Heart Association, preconiza um consumo de colesterol de $300 \mathrm{mg} / \mathrm{dia}$. Além do que, a carne suína é grande fonte de vitamina e minerais, tendo destaque para o cálcio, fósforo, zinco, ferro e potássio (ABCS, 2018; Heart, 2018). Entretanto, é importante salientar que existem pessoas que estão expostas a uma série de fatores de risco, que as predispõem ao acúmulo de colesterol nos vasos sanguíneos, podendo contribuir para aumento das doenças cardiovasculares, não podendo associar ao fato de consumir carne suína (Roppa, 2006).

Visando o mercado cada vez mais exigente, a Embrapa, após estudos lançou o "Suíno Light" o MS58 há 18 anos e recentemente a fêmea MO25C foi lançada. Essa linhagem tem como diferencial uma carne com baixo teor de gorduras (EMBRAPA, 2014). Atualmente, existem diversas genéticas de suínos para atenderem a demanda do mercado consumidor.

\section{Um novo olhar sobre a carne suína}

De acordo com os resultados da pesquisa realizadas pela ABCS, finalizada em 2004, demonstrando os vários motivos para o não consumo da carne suína, a associação vem buscando maneiras para que muitos desses mitos sejam desmistificados e a população brasileira possa vir a consumir mais carne suína. Os resultados foram o ponto de partida para a estruturação de uma Política Nacional de Marketing para a carne suína. Tendo como etapas, a preparação da cadeia produtiva, seguida a promoção de campanhas em vários estados no Brasil incentivando o consumo e desmistificando os mitos, tendo como tema "UM NOVO OLHAR SOBRE A CARNE SUÍNA", demonstrando as qualidades do produto para o grande público através da televisão, do rádio, dos jornais e das revistas - as mídias de massa. Em setembro de 2018, a ABCS promoveu a Semana Nacional da Carne Suína com o objetivo de demonstrar a qualidade e a saudabilidade da carne suína.

\section{Biosseguridade na suinocultura}

Atualmente, a biosseguridade é um fator preponderante dentro da produção suinícola. Tendo por objetivo inserir um conjunto de manejo de boas práticas na granja, podendo ser utilizadas na prevenção da introdução de doenças infecciosas ou parasitárias em qualquer sítio de produção (ABCS, 2011). Segundo o Manual de Boa Práticas (2011), desenvolvido pela EMBRAPA e pela ABCS, dentro do contexto de biosseguridade, engloba-se vários pontos importantes em torno da granja de criação suína, como: a barreira verde, objetivando evitar a entrada de patógenos através do vento; cercas de isolamento, impedindo que outros animais adentrem as instalações, evitando possíveis transmissões de doenças; restrição do acesso de veículos e/ou caminhões para dentro do perímetro da granja e banho e/ou troca de roupas dos funcionários que fazem o manejo dos animais, por vezes utilizando de roupas descartáveis, para que microrganismos patogênicos não sejam levados até os animais; destinação correta de lixos e um adequado manejo de dejetos, evitando que a carga poluente seja lançada sem tratamento no curso dos rios, contaminando a água e animais e humanos que consumirem (EMBRAPA, 2003; ABCS, 2011).

Além do manejo fora da granja, o manejo dos animais e do interior da granja é de suma importância. O programa de vacinação de acordo com a faixa etária é fundamental, uso de medicação correta e respeito ao período de carência até o abate, o controle de ectoparasitas e endoparasitas (principal preocupação dos consumidores), controle de moscas e roedores, quarentena para os animais que são comprados de outras propriedades, evitando a disseminação de alguma possível doença que esteja ainda no período de incubação (EMBRAPA, 2003; ABCS, 2011). O principal manejo no interior da granja indispensável no programa de biosseguridade e em todas as fases da criação é a limpeza diária, que é imprescindível para manter o ambiente em boas condições, evitando a proliferação bacteriana e/ou parasitária. Ao final de um ciclo de produção, a limpeza e desinfecção, em conjunto com o vazio sanitário são importantes para que próximo lote de animais seja alojado em um ambiente mais limpo possível. A água oferecida aos animais deve ser limpa e de boa qualidade, bem como a alimentação (EMBRAPA, 2003; ABCS, 2011). 


\section{A Suinocultura aliada à saúde humana}

Desde o final do século XIX, o suíno vem sendo utilizado como um modelo cirúrgico experimental na medicina humana, devido principalmente à semelhança que ambos possuem no trato gastrointestinal. Devido essa similaridade, muitos estudos vêm sendo realizados e hoje, o suíno é um artifício muito utilizado em várias áreas da medicina. A produção de suínos transgênicos já é uma realidade, com essa técnica é possível a obtenção de hemoglobina humana produzida pelo suíno transgênico, uma alternativa as transfusões sanguíneas (Roppa, 2006; Vaena et al., 2013).

Além da hemoglobina, o suíno também oferece outras substâncias que são importantes para manutenção do organismo humano e para o controle de doenças. Rotineiramente já vem sendo utilizada: a insulina do pâncreas para pessoas diabéticas, o ACTH (adrenocorticóide) da glândula pituitária para tratamento de artrites e doenças inflamatórias, a tireoide para fabricação de medicamento para pessoas com hipotireoidismo. Da mesma forma, da mucosa intestinal é retirado a heparina que serve como anticoagulante e o surfactante dos pulmões que é utilizado em neonatos com síndrome da imaturidade pulmonar. Além da utilização de partes suínas para os xenotransplantes, com a utilização de pele, válvulas cardíacas e fígado (Roppa, 2006).

\section{Considerações finais}

Vários mitos sobre a carne suína hoje em dia não possuem mais fundamentação devido às melhorias nas condições de criação dos suínos que foram ocorrendo ao longo dos anos. Antigamente os animais eram criados em pocilgas e uma alimentação baseada em resto de alimento. Atualmente as granjas de suínos são extremante limpas com manejo sanitário adequado e a alimentação oferecida é exclusivamente de ração. A partir disso, carne disponível atualmente é de boa qualidade e rica em vitaminas e minerais, sendo oposta a visão que grande parte da população acredita ser. Campanhas informativas são alternativas fundamentais para que a mudança de pensamento aconteça. De qualquer forma, ainda existe um extenso caminho para que a ocorra total desmistificação cravada sobre a carne suína.

\section{Referências}

ABCS: Associação Brasileira dos Criadores de Suínos. Disponível em: $<$ http://www.abcs.org.br/producao/genetica/1 75-historia-dos-suinos>. Acesso em 18 de Junho de 2018.

ABCS: Associação Brasileira dos Criadores de Suínos. Manual brasileiro de boas práticas agropecuárias na produção de suínos. 2011. Disponível em:< http://www.acrismat.com.br/novo site/arquiv os/27012012124348manual_brasileiro.pdf $>$.

Acesso em 28 de Junho de 2018.

ABPA - Associação Brasileira de Proteína Animal. Disponível em: < http://www. http://abpa-br.com.br > Acesso em 28 de junho de 2018.

APS: Associação Paranaense de Suinocultores. Disponível em: $<$ http://aps.org.br/noticias/1timas/693-carne-suina-lidera-producao-econsumo-mundial-.html>. Acesso em: 12 de Julho de 2018.

Cannon, J.E., Morgan, J.B., Mckeith, F.K., Smith, G.C., Sonka, S., Heavner, J. \& Meeker, D.L. 1996. Pork chain quality audit survey: quantification of pork quality characteristics. Journal of Muscle Foods, 7, 29-44.

Cardoso, M. 2009. O que representam os suínos na transmissão de zoonoses para humanos?. Acta Scientiae Veterinariae, 37(Supl 1), 81-89.

Carvalho, T.B. Estudo da elasticidade-renda da demanda de carne bovina, suína e de frango no Brasil. 2007. Escola Superior de Agricultura Luiz de Queiroz, Universidade de São Paulo, Piracicaba, 88p.

CDC: Centers for Disease Control and Prevention. Disponível em:< http://www.cdc.gov/parasites/taeniasis/biolog y.html >. Acesso em 26 de Junho de 2018.

Costa, C.N., Fávero, J.A., Leitão, G.R. 1984. Evolução das características de desempenho e carcaça em suínos submetidos a teste de progênie em Santa Catarina, 73, 1-4, abril.

EMBRAPA: Empresa Brasileira de Pesquisa Agropecuária .2003. Disponível em: $<$ http://sistemasdeproducao.cnptia.embrap a.br/FontesHTML/Suinos/SPSuinos/manejode jetos.html>. Acesso em 28 de junho de 2018.

EMBRAPA: Empresa Brasileira de Pesquisa Agropecuária. 2014. Disponível em:< https://www.embrapa.br/busca-de-noticias//noticia/2184427/suino-light-abre-espaco- 
para-novos-mercados-e-produtores>. Acesso em 27 de Junho de 2018.

Fávero, J.A. \& Figueiredo, E.A.P. 2009. Evolução do melhoramento genético de suínos no Brasil, Revista Ceres, 56(4), 420-427.

Fávero, J.A. \& Guidoni, A.L. 2001. Normatização e padronização da tipificação de carcaças de suínos no Brasil - aspectos positivos e restrições, $2^{\mathrm{a}}$ Conferência Internacional Virtual sobre Qualidade de Carne Suína, Concórdia, Santa Catarina, p.73-79.

Fortes, E. Parasitologia Veterinária. $4^{\mathrm{a}}$ ed. São Paulo: Ícone Editora. 2004. 607p.

Heart: American Heart Association. Disponível em: $<$ http://www.heart.org/>. Acesso em $26 \mathrm{de}$ Junho de 2018.

Magnoni, D., Pimentel, I. 2007. A importância da carne suína na nutrição humana. Disponível em:

$<$ http://www.abcs.org.br/attachments/0994.pd f>. Acesso em 18 de Junho de 2018.

Medeiros, F., Tozzetti, D., Gimenes, R. \& Neves, M. F. 2008. Complexo teníase-cisticercose. Revista Científica Eletrônica de Medicina Veterinária,6, 11, 1-6.

Ministério da Agricultura. Mapa alerta para os perigos do consumo de carne sem fiscalização. Disponível em: < http://www.agricultura.gov.br/comunicacao/n oticias/2013/02/mapa-alerta-para-os-perigosdo-consumo-de-carne-sem-fiscalizacao >.

Acesso em 12 de Julho de 2018.

Moreira, P.R.R., Zafalon, L.F., Jorge, P.S. 2003. Número de casos de cisticercos detectados em bovinos, em matadouro localizado na região de Ribeirão Preto, no período de agosto a novembro de 2003. Unimar Ciências, 12, (1/2), $55-60$

Navarro, I.T. Complexo Teníase - Cisticercose. Disponível em:< http://www.zoonoses.org.br/absoluto/midia/i magens/zoonoses/arquivos_1330097119/3228 _complexo_teniase_cisticercose.pdf $>$. Acesso em 12 de Julho de 2018.

Poletto, A.R., Filho, J.I.S., Barni, E.J. 2001. Avaliação do potencial de mercado dos produtos industrializados derivados de suíno. $2^{\mathrm{a}}$ Conferência Internacional Virtual sobre Qualidade de Carne Suína, Concórdia, Santa Catarina, p.1-28.

Rehfeldt, C., Fiedler, I., Dietl G. \& K.Ender. 2000. Myogenesis and postnatal skeletal muscle cell growth as influenced by selection. Livestock Production Science, 66, 177-188.

Rodrigues, D.C., Toseti L.B., Sitanaka, N.Y., ; Memrava, F. K., Theil, P., Filardi, R.S. . Mitos $e$ preconceitos sobre a carne suína entre universitários da Unesp - Campus Ilha

Roppa, L. 2006. Carne suína: mitos e verdades, Disponível em: <http://www.abcs.org.br/attachments/0995.pd f $>$. Acesso em 18 de Junho de 2018.

Sarcinelli, M.F., Venturini, K.S., Silva, L.C. Produção de Suínos - Tipo Carne, Boletim Técnico, UFES. Disponível em: < http://www.agais.com/telomc/b00507_carne_s uinotipocarne.pdf $>$. Acesso em 18 de Junho de 2018

Vaena, M.L.H.T., Andrade, B.G.A., Souza, D.B., Oliveira, A. L. A., Marques, R. G. \& Atallah, F. A. 2013. Aspectos históricos da cirurgia experimental animal e sua importância no desenvolvimento da cirurgia. Revista Brasileira de Medicina Veterinária, 35(supl.1), 101-106.

Viana, D.C., Santos, A.C., Rui, L.A., Prado, A. A. F. \& Anunciação, A. R. A. 2012. Incidência de cisticercose suína através da inspeção de animais abatidos no abatedouro municipal de Imperatriz entre 2000 a 2010, Maranhão, Brasil. Enciclopédia Biosfera, Centro Científico Conhecer, 8(15), 1043-1051.

Recebido: 22 outubro, 2018.

Aprovado: 14 novembro, 2018.

Publicado: 27 dezembro, 2018.

Licenciamento: Este artigo é publicado na modalidade Acesso Aberto sob a licença Creative Commons Atribuição 4.0 (CC-BY 4.0), a qual permite uso irrestrito, distribuição, reprodução em qualquer meio, desde que o autor e a fonte sejam devidamente creditados. 